\title{
鼠 \\ MAKNA SIMBOLIK TOPENG SAKURA PADA MASYARAKAT ADAT LAMPUNG
}

\author{
Fauzan \\ IAIN Raden Intan Lampung \\ fauzan@iainradenintan.ac.id
}

\begin{abstract}
Abstrak
Sakura merupakan tradisi yang dikembangkan oleh masyarakat adat Lampung di wilayah Lampung Barat. Dalam pelaksanaannya, sakura dilakukan dengan kegiatan pawai taritarian dengan mengenakan topeng. Sakura mengandung makna simbolik dan melambangkan bermacam-macam karakter yang bisa dimainkan oleh manusia. Setiap orang bebas menentukan karakter dan peran yang akan dimainkannya dalam kehidupan. Jenis sakura helau dan sakura kamak mengandung makna ajakan pada kelompok masyarakat yang kaya dan kelompok miskin untuk menghilangkan perbedaan status sosial serta bersatu padu dalam memajukan daerahnya.
\end{abstract}

\begin{abstract}
Sakura is a tradition that was developed by the indigenous people of Lampung in Lampung Barat region. The tradition is implemented in parade dances with masks. Sakura contains the symbolic meanings and symbolizes an assortment of characters that can be played by humans. Everyone is free to determine his or her characters and role to play in life. The Sakura Kamak and Sakura Helau imply an invitation to the rich and the poor of the
\end{abstract}


community to eliminate the differences in social status and to join in promoting the region.

Key Word: Makna Simbolik, Topeng Sakura, Adat Lampung.

\section{A. Pendahuluan}

Sakura adalah salah satu jenis kesenian tradisional yang berasal dari Lampung Barat. Kesenian Sakura merupakan pesta topeng yang dilaksanakan setiap idul Fitri oleh masyarakat Lampung Barat, khususnya di wilayah Skala Brak, Liwa Kabupaten Lampung Barat. Menurut penelitian yang dilakukan I Wayan Mustika, kata "Sakura" berasal dari kata "Sakukha" yang berarti penutup muka atau penutup wajah. Perubahan kata "sakukha" menjadi "sakura" lebih karena mengikuti perkembangan tata bahasa Indonesia secara umum, agar masyarakat Lampung lokal maupun pendatang dapat dengan mudah mengucapkannya. ${ }^{1}$

Sakura dalam kebudayaan Lampung ini memiliki arti topeng/ penutup wajah atau merubah penampilan yang menggambarkan berbagai bentuk sifat dimuka bumi ini. Pesta Sakura yang ada pada masyarakat Lampung Barat ini menggambarkan suasana kegembiraan dan kebebasan berkreasi dan berekspresi dalam kebersamaan kelompok. Pesta Sakura secara definisi merupakan perayaan dan atau ungkapan kegembiraan masyarakat secara bersama-sama dengan bertopeng (menutup wajah) dan merubah penampilan sedemikian rupa yang sifatnya menghibur dengan tujuan utama bersilaturahim. Puncak perayaan pesta Sakura dilaksanakan dengan panjat pinang secara berkelompok dengan sistim beguai jejama (gotong royong). ${ }^{2}$

${ }^{1}$ I Wayan Mustika, Perkembangan Bentuk Pertunjukan Sakura Dala Konteks Kehidupan Masyarakat Lampung Barat Tahun 1986-2009, Ringkasan Disertasi dalam Rangka Ujian Terbuka, UGM Tahn 2011.

${ }^{2}$ Endang Guntoro Canggu, Tradisi dan Masa Depan Kekuatan Sebuah Kebudayaan: Memaknai Pesta Budaya Sekura Cakak Buah di Lampung Barat, dalam http//www. endangguntoro canggu.blogspot.com/2009/02/tadisi-dan-masa- 
Menurut pengamatan I Wayan Mustika, tradisi sakura yang sebelumnya digunakan sebagai media untuk pemujaan terhadap penguasa alam semesta dan roh-roh nenek moyang kini telah berubah menjadi media hiburan saja. Sakura yang pada awalnya sebagai sebuah bentuk upacara ritual (pesta panen), berubah menjadi sebuah tontonan biasa untuk menyambut hari raya idul Fitri. ${ }^{3}$

Namun demikian, pandangan I Wayan Mustika tersebut tidak semuanya benar. Sebagai sebuah produk budaya, sakura merupakan hasil dari keseluruhan sistem gagasan, tindakan dan hasil karya manusia, yang tentunya bermakna bagi manusia atau masyarakat Lampung. Oleh karena itu, jika keberadaan tradisi Sakura yang dihasilkan pada masa pengaruh Hindu masih bertahan hingga saat ini (Islam), yang terjadi adalah akulturasi. Dalam proses akulturasi itu, kebudayaan baru yang datang diolah dan lambat laun unsur-unsurnya diterima tanpa harus kehilangan kebudayaan asli itu sendiri. ${ }^{4}$ Artinya, dalam tradisi Sakura yang ada di Lampung Barat saat ini terdapat nilai-nilai atau unsur-unsur yang tetap dijaga dan dilestarikan (kontinuitas) oleh masyarakat yang memilikinya.

Hal itu sejalan dengan pandangan Endjat Djaenu Derajat yang melihat bahwa topeng Lampung (Sakura) sebagai bentuk kesenian tradisional masyarakat Lampung menunjuk pada norma-norma komunal masyarakat pendukungnya. Normanorma tersebut mencakup dimensi organisasi sosial, dimensi sosial, dan dimensi keagamaan. Pada dimensi organisasi sosial, kesenian Topeng Lampung menunjukkan sistem pewarisan, sistem rekrutmen, dan sistem organisasi. Sedangkan pada dimensi sosial kesenian Topeng Lampung berfungsi sebagai media sosialisasi, media solidaritas, dan sebagai media rekreasi.

depan-kekuatan-sebuah.html. diunduh pada Rabu 27 Maret 2013 Pukul 13.41. WIB.

${ }^{3}$ I Wayan Mustika, Perkembangan Bentuk, h. 3.

${ }^{4}$ Koentjaraningrat, 1980, Pengantar Пlmu Antropologi, (Jakarta: Aksara Baru), h. 262. 
Adapun pada dimensi keagamaan, kesenian Topeng Lampung pada hakekatnya merupakan sarana ritus-ritus keagamaan/ religi yang digunakan sebagai: 1) pelestarian dari tradisi ilmu sihir, penggunaan mantera, do'a, sesaji, jimat, dan tabu-tabu; 2) suasana pergelaran cenderung memotivasi para penarinya ke tingkat rohaniyah yang lebih tinggi; 3) menampilkan perlambang pergolakan sosial budaya yang berwujud jihad dan patriotisme; dan 4) media komunikasi propaganda dan dakwah. ${ }^{5}$

Tulisan ini selanjutnya diarahkan untuk menemukan nilai-nilai atau makna yang ada di balik tradisi Sakura yang dilakukan di oleh masyarakat adat Lampung, khususnya di wilayah Lampung Barat. Secara keseluruhan tulisan ini difokuskan pada upaya pencarian nilai atau makna yang ada di balik tradisi Sakura. Secara operasional, tulisan ini menyoroti prosesi tradisi sakura di Lampung Barat serta menggali makna simbolik yang ada di dalamnya. Tulisan ini dilakukan dengan cara mendeskripsikan gejala, peristiwa, kejadian yang terjadi pada saat sekarang terkait dengan Sakura.

\section{B. Kerangka Konseptual}

Kebudayaan sebenarnya terdiri dari gagasan-gagasan, simbol-simbol dan nilai-nilai sebagai hasil karya dan perilaku manusia, sehingga tidak berlebihan bila dikatakan bahwa manusia itu "makhluk bersimbol". Dalam arti yang lain dunia kebudayaan adalah dunia penuh simbol. Manusia berpikir, berperasaan dan bersikap dengan ungkapan-ungkapan yang simbolis, seperti yang dikatakan oleh Ernest Cassirer bahwa ungkapan yang simbolis ini merupakan ciri khas dari manusia yang dengan jelas membedakannya dari hewan, sehingga manusia disebut dengan "animal symbolycum" atau hewan

\footnotetext{
${ }^{5}$ Endjat Djaenu Derajat, dkk, “Topeng Lampung: Tinjauan Awal Drama Tari Tupping dan Pesta Sakura”, (Bandar Lampung : Departemen Pendidikan dan Kebudayaan Kantor Wilayah Propinsi Lampung, 1993).
} 
yang bersimbol. ${ }^{6}$ Dikatakan dalam buku yang berbeda bahwa melalui simbol manusia dapat menciptakan suatu dunia kultural yang didalamnya terdapat bahasa, mitos, agama, kesenian dan ilmu pengetahuan. Sedangkan menurut Susanne K. Langer, dalam kajian makna proses simbolisasi suatu obyek estetik menjadi penting karena makna secara tajam dapat diamati pada proses penyimbolan serta fenomena atau juga penyimbolan gagas estetik.?

Kenyataan manusia sebagai animal symbolicum dikarenakan manusia sesuai struktur anatominya mempunyai sistem reseptor dan sistem efektor. Sistem reseptor berfungsi menerima rangsangan dari luar. Sedangkan sistem efektor berfungsi pereaksi terhadap rangsangan dari luar. Kedua sistem itu dalam satu ikatan yang sama disebut lingkaran fungsional binatang. Lingkaran fungsional itu dapat berubah secara kuantitatif maupun kualitatif. Faktor itulah yang membedakan manusia dengan binatang. Oleh karenanya manusia dalam kehidupannya banyak menggunakan simbol-simbol.

Secara etimologis simbol dan simbolisme diambil dari kata Yunani sumballe (sumballein), yang dapat diartikan: berwawancara, merenungkan, memperbandingkan, bertemu, melemparkan menjadi satu, menyatukan. Budiono Herusatoto (2000) mengajukan istilah "simbolos" yang diartikan tanda atau ciri yang memberitahukan sesuatu hal kepada seseorang. Lebih lanjut Budiono mengartikan simbol sebagai sesuatu hal/ keadaan yang merupakan media pemahaman terhadap obyek. Maka bentuk simbol dapat diartikan penyatuan dua hal yang

${ }^{6}$ Dalam Mifedwil Jandra, dkk., Perangkat/Alat-alat dan Pakaian Serta Makna Simbolis Upacara Keagamaan di Lingkungan Keraton Yogyakarta, (Yogyakarta, Proyek Inventarisasi dan Pembinaan Nilai-nilai Budaya DIY, 1989-1990), h. 2. Lihat Juga Hans J. Daeng, Manusia, Kebudayaan dan Lingkungan, Tinjauan Antropologis, (Yogyakarta: Pustaka Pelajar, 2000), h. 26.

${ }^{7}$ Agus Sachari, Estetika: Makna, Simbol dan Daya, (Bandung, ITB, 2002), h. 14 . 
luluh menjadi satu. Dalam simbolisme subyek menyatukan dua hal menjadi satu. ${ }^{8}$

Simbol dan simbolisasi dapat diartikan dua macam pemikiran. Satu pihak melihat simbol sebagai sesuatu yang imanen. ${ }^{9}$ Dirasa pada diri manusia serba terkurung, masih terpengaruh unsur lain. Di lain pihak ada pemikiran yang mengatakan bahwa simbol itu transenden dan dalam dialog dengan yang lain akan ditemukan jawaban. Menurut pandangan pihak ini simbol tidak hanya berdimensi horizontal imanen melainkan juga berdimensi transenden. Pendek kata simbol berdimensi metafisika.

Simbol juga mengungkapkan aspek-aspek terdalam bahwa kenyataan tidak terjangkau oleh alat pengenalan lain. Gambar, simbol dan mitos berfungsi mengungkapkan masalah modalitas (ada yang paling rahasia). Bila hal ini dikaji secara mendalam akan mengenal manusia sebelum terjalin dalam peristiwa sejarah. Rupa simbol-simbol dapat berubah, tetapi fungsinya tetap sama. Simbol, mitos dan ritus selalu mengungkapkan suatu situasi yang membatasi manusia dan tidak hanya dalam siatuasi sejarah saja. Situasi batas adalah situasi yang ditemukan manusia secara sadar dan bersifat universial. Semakin manusia mengangkat diri dari momen sejarahnya dan membiarkan keinginannya menghayati peranannya, maka manusia makin menjadikan dirinya sebagai makluk yang penuh dan utuh. ${ }^{10}$ Simbol-simbol dan gambargambar sekedar sarana masuk ke dunia adi-sejarah. Meskipun pemikiran simbolik menjadikan kenyataan yang langsung terbuka (transenden). Tetapi pemikiran itu tidak merusak atau mengaburkan nilai kenyataan.

${ }^{8}$ Budiono Herusatoto, Simbolisme Dalam Budaya Jawa, (Yogyakarta: Hanindita Graha Widia, 2000), h. 11

${ }^{9}$ Lihat dalam C.A. Van Peursen, Strategi Kebudayaan, terj. Dick Hartono, (Yogyakarta: Kanisius, 1976).

${ }^{10}$ Rahmat Subagya, Agama Asli Indonesia, (Jakarta: Siar Harapan, 1981). 
Lebih lanjut James P. Spradley mengatakan bahwa semua makna budaya diciptakan dengan menggunakan simbol-simbol kata. ${ }^{11}$ Makna hanya dapat disimpan di dalam simbol, ujar Clifford Geertz. ${ }^{12}$ Pengetahuan kebudayaan lebih dari suatu kumpulan simbol, baik istilah-istilah rakyat maupun jenis-jenis simbol lain. Semua simbol, baik kata-kata yang terucapkan, sebuah obyek seperti sebuah bendera, suatu gerak tubuh seperti melambaikan tangan, sebuah tempat seperti masjid atau gereja, atau seperti perkawinan, merupakan bagian-bagian suatu sistem simbol. Simbol adalah obyek atau peristiwa apapun yang dapat kita rasakan atau kita alami. ${ }^{13}$

Sebagian orang bahkan ada kalanya menggantungkan nasib dan keselamatan mereka pada simbol-simbol atau lambang-lambang tertentu. Mereka memilih hari dan tanggal untuk menikah, pindah rumah sebagai contohnya. Untuk memperoleh keberuntungan atau keselamatan ada pula pihak menanam kepala kerbau sebelum membangun sebuah gedung, menaruh sesaji didekat sebuah pohon besar, batu besar atau makam yang dianggap keramat. Untuk mencapai keinginan tertentu, seperti sukses dalam bisnis atau mendapatkan jodoh kita memakai cincin atau susuk tertentu.

Setiap bentuk upacara adat yang bersifat religi salalu disertai dengan simbol-simbol. Simbol dapat diartikan dengan tanda, ciri yang memberitahukan sesuatu hal kepada seseorang. Budiono Herusatoto mendefinisikan simbol atau lambang adalah sebagai sesuatu hal atau keadaan yang merupakan pengantara pemahaman terhadap obyek. Dengan demikian simbol merupakan penggambaran suatu obyek. Lambang atau simbol mempunyai suatu fungsi sebagai media untuk berkomunikasi dengan sesamanya. Sesungguhnya

${ }^{11}$ James P. Spradley, Metode Etnografi, (Yogyakarta: Tiara Wacana, 1997), h. 121.

${ }^{12}$ Clifford Geertz, Tafsir Kebudayaan, (Yogyakarta: Kanisius, 1992), h. 51

${ }^{13}$ Alex Sobur, Psikologi Umum, (Bandung: Pustaka Setia, 2003), h. 177. 
lambang-lambang yang dikembangkan oleh manusia tidak hanya mempunyai arti sebagaimana terkandung didalamnya, akan tetapi yang lebih penting adalah dayanya. Lambang tidak sekedar menunjukan ide tetapi juga mempunyai kekuatan sebagai perangsang. ${ }^{14}$

Jadi lambang bagi manusia pendukungnya tidak sekedar mengandung makna akan tetapi ia mengandung arti apa yang dilaksanakan orang dengan makna tersebut. Penggunaan simbol dalam budaya merupakan alat perantara yang berasal dari nenek moyang untuk melukiskan segala macam bentuk pesan pengetahuan kepada masyarakat sebagai generasi penerus yang diwujudkan dalam tindakan sehari-hari mereka sebagai makhluk budaya diharapkan mampu memberi pemahaman bagi masyarakat penggunanya. Adapula anggapan lain mengenai definisi kebudayaan yang berkaitan dengan simbol yaitu, kebudayaan merupakan elemen subyektif dan obyektif yang dibuat manusia yang di masa lalu meningkatkan kemungkinan untuk bertahan hidup dan berakibat dalam kepuasan pelaku dalam ceruk ekologis, dan demikian tersebar diantara mereka yang dapat berkomunikasi satu sama lainnya, karena mereka mempunyai kesamaan bahasa dan mereka hidup dalam waktu dan tempat yang sama. ${ }^{15}$

Oleh karena itu, inti penting dari budaya adalah pandangan yang bertujuan untuk mempermudah hidup dengan mengajarkan orang-orang bagaimana cara beradaptasi dengan lingkungannya. Perlu diketahui, budaya sendiri memiliki beberapa element yang menyertainya, misalnya sejarah, agama, nilai, organisasi sosial, bahasa, dan masih banyak lagi. Hal tersebut yang menjadikan identitas bagi suatu daerah. Masing-masing daerah memiliki simbol-simbol tertentu

${ }^{14}$ Budiono Herusatoto, Simbolisme Dalam Budaya Jawa, (Yogyakarta: Hanindita Grahawidia, 2000), h. 10.

${ }^{15}$ Larry A. Samovar, dkk, Komunikasi Lintas Budaya, (Jakarta: Salemba, 2010), h. 27 
dalam budayanya. Tindakan simbolis inilah salah satunya yang sampai saat ini masih diyakini dan dilestarikan.

Dalam kehidupan kebudayaan nasional yang sedang berkembang, upacara dengan berbagai simbolik-nya mencerminkan norma-norma serta nilai-nilai budaya suatu suku bangsa di Indonesia. Merupakan suatu unsur penting yang ikut menentukan identitas serta warna kehidupan budaya bangsa Indonesia. Upacara - upacara amat akrab, komunikatif dan telah memegang peranan yang penting dalam menciptakan kondisi yang mempertebal rasa aman dan memberi pegangan dalam menentukan sikap bagi segenap warga masyarakat yang bersangkutan, atau disebut sebagai sarana komunikasi bahkan sarana sosialisasi bagi masyarakat tradisional khususnya. Perangkat lambang (simbolik) dalam suatu upacara pada hakekatnya bermakna sebagai pengatur tingkah laku disamping berfungsi sebagai sumber informasi. Sekaligus merupakan petunjuk bahwa sesungguhnya manusia mampu membuktikan dirinya sebagai mahluk yang berbudi luhur. Melalui perantaraan lambang-lambang manusia dapat menyebar luaskan kebudayaan, karena tidak hanya sekedar mengandung makna, tetapi juga merangsang orang untuk bersikap sesuai dengan makna lambang. ${ }^{16}$

\section{Sejarah Kemunculan Topeng Sakura}

Dalam khazanah budaya nusantara, penggunaan istilah topeng telah disebutkan dalam Prasasti Wahara Kuti atau prasasti Jaha pada tahun 762 Shaka (840 Masehi) dengan nama Atapukan atau Tapel. ${ }^{17}$ Sumber lain yang mengukuhkan keberadaan pertopengan atau topeng terngkap dalam prasasti Bebetin 818 Shaka (896 Masehi). Ungkapan yang menyebutkan

${ }^{16}$ Murtiadji, R. Sri Supadmi dan R. Suwardanidjaya, Tata Rias Pengantin Gaya Yogyakarta, (Jakarta: Gramedia Pustaka Utama, 1993), h. 7.

${ }^{17}$ Claire Hot, Melacak Jejak Perkembangan Seni di Indonesia, terj. RM. Soedarsono (Bandung: Masyarakat Seni Pertunjukan Indonesia, 2000), h. 428 
keberadaan topeng juga terdapat dalam Prasasti Gurun Pai Desa Pandak Badung yang menyebutkan...yan amukul (juru tabuh), anuling (seruling), atapukan (tapel/topeng).... Prasasti ini diduga dibuat ketika pemerintahan raja Anak Wungsu pada tahun 993 Sakha (1071 Masehi). ${ }^{18}$

Berdasarkan uraian di atas, topeng yang disebut dengan istilah atapukan, partapukan, dan tapel, sudah dikenal oleh suku bangsa-suku bangsa di nusantara sejak abad IX. Dengan demikian topeng yang dikenal dalam budaya Indonesia hingga kini merupakan salah satu hasil karya seni dan budaya manusia yang diduga usianya setua usia manusia itu sendiri. Hal ini bisa dipahami mengingat informasi di masa lalu (prasejarah) berita-berita tentang topeng atau artefak sejenisnya berjalan sangat lambat.

Pada awalnya topeng merupakan salah satu wujud penggambaran simbolis yang dibuat oleh manusia untuk maksud penghormatan kepada leluhur dengan menggunakan berbagai bahan sesuaikeperluan masyarakat di zamannya. Sehingga maksud penggunaan topeng adalah sebagai media pemanggilan roh nenek moyang agar memsauki topeng-topeng dalam sebuah upacara animistik. Pada upacara seperti ini topeng berfungsi sebagai sarana penghubung antara manusia dengan alam ghaib atau antara roh nenek moyang dengan keluarga yang melaksanakan suatu upacara. Upacara semacam ini disebut Srhaddha yang dilaksanakan oleh Raja Hayam Wuruk dari Majapahit, ketika memperingati 12 tahun Sri Raja Padmi wafat. Pelaksanaan upacara Shraddha dilangsungkan di sebuah area pemakaman dengan dibuat sebuah bentuk topeng yang disebut Sang Hyang Puspashariro. ${ }^{19}$

${ }^{18}$ I Made Bandem dan I Nyoman Rembang, Perkembangan Topeng Bali Sebagai Seni Pertunjukan, (Bali: Proyek Penggalian Pembinaan Pengembangan Seni Klasik/Tradisional dan Kesenian Baru Pemerintah Daerah Tingkat I Bali, 1976), h. 3.

${ }^{19}$ Kuswadji Kawindrosusanto dan Rachmadi Ps, Topeng-topeng Klasik Indonesia, (Yogyakarta: Panitia Pameran Topeng Klasik Indonesia Yogyakarta, 
Ditinjau dari aspek kesejarahannya, hingga saat ini belum diketahui secara pasti awal mula pesta topeng sakura ini dimulai, siapa penyelenggaranya, siapa pelaku, siapa pula yang terlibat. Kita hanya dapat menduga, karena tidak ada sumber yang benar benar bisa dipertanggung jawabkan. Dalam penelitiannya, Lilia Aftika menyebukan bahwa ada dua versi terkait asal mula pesta Sakura ini, versi pertama menyebutkan bahwa pesta sakura sudah ada sejak zaman Hindu. Topengtopeng yang dikenakan merupakan penjelmaan orang-orang yang dikutuk dewa karena berbuat tidak terpuji. Perbuatan tidak terpuji yang dimaksud adalah tidak mengakui adanya dewa yang patut disembah. Akibatnya, rupa mereka menjadi buruk. Versi kedua, menyebutkan pesta sakura berasal dan bermula pada zaman Islam. Alasannya, pelaksanaan acara ini diadakan untuk memeriahkan dan menyambut Hari Raya Idul Fitri dan umat yang merayakan Idul fitri adalah umat Islam. "Tidak jelas tahun dan abad berapa acara ini mulai diadakan, tetapi menurut perkiraan, Islam menyebar di Lampung Barat sekitar abad ke-13. Dengan demikian, timbul anggapan sekuraan diadakan pertama kali sekitar abad ke-13. Dalam hal ini Lilia berkeyakinan bahwa versi kedua di atas tampaknya lebih meyakinkan dan lebih masuk akal. Alasan yang menguatkan, yaitu hari perayaannya menggunakan tanggal Islam dan hari raya Islam. Di samping itu, dalam pelaksanaannya tidak menunjukkan dan menonjolkan tokohtokoh seperti dewa-dewa atau nama-nama yang berkaitan ajaran Hindu. ${ }^{20}$

Namun demikian keyakinan Lilia tersebut tidak sejalan dengan analisa Fachruddin. Dalam blognya Fachrudin menuliskan bahwa .... "Dan karena waktunya bersamaan dengan perayaan Idul Fitri maka banyak pihak menduga

1970), h. $5-7$.

${ }^{20}$ Dalam http://blog.ugm.ac.id/2010/10/30/pesta-rakyat-topeng-sekuradi-desa-pangkul/, diunduh pada Rabu, 27 Maret 2013 pukul 14:55 WIB. 
acara ini tak terlepas dari upaya penyebaran Islam di daerah setempat. Namun Islam masuk ke daerah ini melalui Sumatera Barat dan Palembang dan kita belum mengenal adanya topeng dari daerah tersebut, yang dijadikan alat dakwah. Kalaupun seandainya Islam masuk melalui Banten, di Banten-pun kita tidak mengenal seni topeng seperti yang di Lampung Barat. Itulah sebabnya maka banyak pihak yang menduga bahwa seni topeng ini muncul dari kepercayaan lokal yang animistik, dan berarti bahwa topeng sakura asli kekayaan milik Lampung. ${ }^{21}$

Kesimpulan Fachrudin tersebut sejalan dengan hasil penelitian yang dilakukan oleh I Wayan Mustika yang menegaskan bahwa Sakura merupakan hasil buatan yang digunakan untuk pemujaan oleh kelompok Buay Tumi pada masa pra sejarah yang memiliki sistem kepercayaan animisme. ${ }^{22}$ Animisme berasal dari bahasa latin anima, yang berarti jiwa atau roh. Bagi masyarakat primitif, semua alam dipenuhi oleh roh-roh yang tidak terhingga banyaknya, tidak saja manusia atau binatang, tetapi benda-benda yang tidak hidup juga memiliki roh, seperti tulang atau batu. Jadi animisme adalah paham tentang semua benda, baik bernyawa dan tidak bernyawa mempunyai jiwa atau roh. ${ }^{23}$ Animisme merupakan agama-agama yang umum bagi orang-orang yang sistem kepercayaannya terhadap kekuatan roh-roh maupun bendabenda, seperti alam, gunung, batu, dan sungai. ${ }^{24}$

Buay Tumi adalah suku Lampung yang paling tua yang mendiami tanah Lampung. Ratu Sekarmong atau Sekarumong

${ }^{21}$ Fachrudin, dalam http://fachruddin54.blogspot.com/2009/09/hitamputih-makna-topeng-sakura.html, diunduh pada Rabu, 27 Maret 2013 Pukul $06.40 \mathrm{WIB}$

${ }^{22}$ Mustika, Perkembangan Bentuk...

${ }^{23}$ Amsal Bakhtiar, Filsafat Agama, Wisata Pemikiran dan Kepercayaan Manusia, (Jakarta: PT. Raja Grafindo Persada, 2007), h. 61-62.

${ }^{24}$ R. Brandon, Jejak-Jejak Seni Pertunjukan di Asia Tenggara, Terj. RM. Soedarsono, (Bandung: P4ST UPI, 2003), h. 10. 
adalah seorang wanita yang menjadi pemimpin masyarakat Buay Tumi pada akhir masa pengaruh Hindu di Skala Berak.

Pada masa pra sejarah sakura merupakan sebuah pertunjukan yang digunakan untuk upacara pemujaan kepada penguasa alam, roh-roh nenek moyang, yang cenderung berwajah jelek dan bertata busana dari daun-daunan atau seadanya. Sakura dahulu ditampilkan oleh kelompok masyarakat Buay Tumi di tempat yang dianggap keramat, seperti tempat pemujaan. Tujuan ditampilkannya sakura ini agar dapat menghadirkan roh leluhur, dan penguasa alam semesta untuk mendapatkan perlindungan atau bantuan, serta terhindar dari kesulitan yang melanda masyarakat desa. Artinya Sakura dibuat untuk kepentingan masyarakat Skala Berak dalam berbagai kegiatan, seperti habis panen padi dan pemujaan untuk keselamatan desa. Bila diperhatikan dari segi bentuk artefak pada wajah Sakura menandakan adanya hubungan yang sangat erat dengan pemujaan terhadap penguasa alam, leluhur, maupun terhadap roh-roh ghaib. ${ }^{25}$

Keberadaan tradisi sakura terus berlangsung sepanjang pengaruh agama Hindu di Buay Tumi. Bahkan pada masa akhir pengaruh Hindu, yaitu masa kepemimpinan Sekarmong, tradisi sakura semakin populer di kalangan masyarakat Buay Tumi di daerah Skala Berak. Sakura tidak saja disajikan setiap panen tiba, tapi juga dilakukan setiap bulan bara (bulan purnama) di alun-alun. ${ }^{26}$

Hingga pada akhirnya datanglah empat orang dari Pagaruyung yang bernama Buay Belunguh, Buay Nyerupa, Buay Pernong atau Kenyangan, dan Buay Bejala Diway. Keempat orang terebut merupakan penyebar agama Islam di Liwa dan berhasil menundukkan Ratu Sekarmong dan menguasai daerah Skala Berak. Pengaruh keempat orang tersebut kemudian mampu merubah keyakinan masyarakat Buay Tumi yang semula

\footnotetext{
${ }^{25}$ Mustika, Perkembangan Bentuk ....

${ }^{26}$ Ibid.
} 
animisme dan memeluk Islam hingga kini. Sejak saat itulah hampir semua kegiatan yang berbau animisme dan Hindu mengalami perubahan mendasar menyesuaikan pada ajaran agama Islam.

Dengan berakhirnya masa kepemimpinan Ratu Sekarmong, masyarakat Liwa mengalami perubahan kebudayaan yang di dalamnya terdapat suatu penekanan terhadap kebiasaan masyarakat Liwa terkait dengan masalah keyakinan. Hal ini sejalan dengan ungkapan Koentjaraningrat yang menggambarkan adanya perubahan dari unsur-unsur budaya yang di dalamya terdapat penekanan yang berkaitan dengan ideologi untuk mempengaruhi kebudayaan-kebudayaan asli bangsa-bangsa yang mereka jumpai di daerah-daerah yang mereka lalui ketika bermigrasi, sehingga menyebabkan perubahan-perubahan dalam kebudayaan itu. ${ }^{27}$

Sejalan dengan masuknya pengaruh Islam di wilayah ini, tradisi Sakura juga ikut mengalami perubahan. Sakura tidak lagi dilaksanakan sebagai bentuk pemujaan terhadap roh-roh, dewa-dewa atau penguasa alam lainnya. Namun Sakura telah berubah menjadi pesta rakyat yang dilaksanakan setelah hari raya idul fitri.

\section{Aktifitas Tradisi Sakura}

Pesta Sakura merupakan suatu pesta rakyat yang diselenggarakan dalam merayakan peristiwa hari raya Idul Fitri untuk mengungkapkan rasa syukur, suka cita, dan perenungan terhadap sikap dan tingkah laku. Istilah sakura menunjuk pada benda/objek penutup wajah yang terbuat dari sepotong kayu/ papan, diukir dalam bentuk/ekspresi yang menggambarkan sifat dan tingkah laku mausia. Ekspresi tersebut memiliki nama dan makna simbolis khusus. Dalam pengertian umum sakura disebut juga topeng kayu. Seseorang dapat disebut

${ }^{27}$ Koentjaraningrat, Sejarah Teori Antropologi II, (Jakarta: UII, 1990), h. 89-90. 
bersakura apabila sebagian atau seluruh wajahnya sudah tertutup. Penutup muka dapat berbentuk bahan polesan dan sesuatu benda yang dirapatkan atau menekan pada wajah. Bahan polesan berupa make-up atau pupur, coretan pada wajah. Benda yang menekan pada wajah berupa kaca mata, kain, sarung, dan sepotong papan kayu yang dipahat dalam bentuk wajah manusia tertentu. ${ }^{28}$

Penyebutan sakura ditentukan oleh tiga unsur: 1) topeng kayu yang menutupi wajah; 2) kelengkapan kostum/ tata busana yang dikenakan; 3) gaya gerak/ tingkah laku pemakai. ${ }^{29}$ Ragam bentuk dan ekspresi topeng apapun dapat dipakai sebagai hasil kreasi dan ungkapan getaran nurani penopeng menjelang acara pesta sakura. Kostum dan gaya gerak menyesuaikan dengan ekspresi, nama dan makna simbolis sebuah topeng kayu.

Peserta pesta sakura menggunakan topeng yang menggambarkan karakter manusia tertentu yang dipadukan dengan tingkah laku dan kelengkapan tata busana. Seluruh lapisan masyarakat terlibat aktif sebagai pencerminan rasa persaudaraan dan kekeluargaan atau kekerabatan pendukung tradisi pesta sakura. Selama pesta berlangsung dihidangkan makanan dan minuman dan juga peserta membawa konsumsi mereka sendiri yang didapat dari hasil berkunjung ke rumahrumah penduduk untuk disantap bersama. Peserta pesta melakukan pawai keliling menyusuri rute perjalanan di sekitar daerah tempat penyelenggaraan pesta. Kemeriahan acara pesta sakura dilengkapi dengan berbagai atraksi kesenian dan pencak silat. Pucak acara pesta diramaikan dengan lomba memanjat pohon pinang.

Bentuk sakura terdiri dari dua jenis, yaitu sakura helau dan sakura kamak. Penamaan kedua jenis sakura ini tidak tergantung dan tidak ditentukan oleh pemakaian bentuk

\footnotetext{
${ }^{28}$ Deradjat, Topeng Lampung..., h. 47.

${ }^{29}$ Ibid., h. 47.
} 
ekspresi topeng khusus, akan tetapi lebih melihat pada aspek kelengkapan tata busana dan gaya gerak dan tingkah laku pemakai. ${ }^{30}$ Kata helau artinya bersih, bagus. Istilah sakura helau mencerminkan kostum yang dikenakan, seluruh kelengkapan tata busana dalam keadaan bersih dan bagus. Sekura jenis ini sering memerankan adegan dan karakter manusia dengan kostum yang lengkap dan rapi.

Beberapa sakura helau yang pernah ditampilkan adalah 1) sakura Pudak Upi, yaitu seseorang berpakaian dengan mode yang serius dikenakan oleh bayi dan bertingkah seperti bayi. 2) sakura Kebayan, di mana pemakai sakura berpakaian dengan model seorang pengantin perempuan, 3) sakura tuha, yaitu penampilan seseorang yang berpakaian dengan model yang sering dikenakan orang tua, dilengkapi dengan atribut dan bertingkah laku sebagai orang tua/kakek. 4) sakura Ngandung, yaitu sakura yang mengenakan pakaian dengan mode yang sering dipakai oleh perempuan hamil, mengganjal perutnya dengan bantal/kain dan bertingkah laku layaknya sedang hamil. ${ }^{31}$

Sedangkan sakura kamak berarti kotor. Kostum yang dikenakan sakura kamak semuanya serba kotor dan compangcamping, bahkan berlumpur. Kelengkapan busana yang dipakai sakura kamak ini antara lain: a) baju dasar kaus dan celana hitam. Kaus dan celana hitam ini dikenakan untuk mengurangi rasa gatal pada tubuh, untuk memberi kesan tidak rapi dan kotor. Kaus yang dipakai dalam keadaan sobek dan penuh noda kotor. Kaus dan celana hitam ini sering dipakai untuk berkebun dan berburu, lalu sengaja disimpan untuk dipakai pada acara sakura dalam memerankan sakuara kamak; b) Seluruh tubuh ditempeli dan dihiasi dengan sampah, daun daun kering, ranting berdaun, rumput-rumputan. Topi atau penutup kepala digunakan ijuk, sehingga wajah tidak kelihatan.

${ }^{30}$ Ibid. h. 60.

${ }^{31}$ Ibid., h. 60-61. 
Karakter sakura kamak diilhami dari kebiasaan berburu hewan di hutan. Kelengkapan busananya mencerminkan hutan rimba. Pakaian kaus dan celana hitam menggambarkan pakaian seorang petani yang lusuh, jelek, compang camping dan kotor. Peran menjadi sakura kamak merupakan karakter kebanggaan dan paling digemari pemakainya. Peran ini lebih memberikan kebebasan pemakai untuk mendandani dirinya dan bebas melakukan gaya gerak. Sebagai sakura kamak tidak membutuhkan kostum dan gaya gerak baku, apabila tubuh sudah berpakaian kotor, compang camping dan ditutupi sampah dan dedaunan serta bertingkah laku bebas, predikat sakura kamak sudah melekat pada diri pemakai.

Beberapa ciri khas dan istimewa sakura kamak di antaranya: 1) dimainkan oleh seorang yang tidak bujang, lagi sudah berkeluarga atau orang tua, ditunjang dengan fisik yang gagah kuat dan mampu melakukan gerakan lincah; 2) menjadi pusat perhatian penonton karena sakura kamak merupakan primadona pesta sakura; dan 3) Nyakak buah dilakukan oleh kelompok sakura kamak.

Penyelenggaraan pesta sakura terdiri dari beberapa tahapan acara sebagai rangkaian proses penyajian pesta rakyat. Beberapa tahapan acara tersebut adalah:

\section{Tahap persiapan.}

Pada tahap persiapan dilakukan kegiatan musyawarah antara ketua-ketua adat dan tokoh-tokoh masyarakat desa untuk membicarakan rencana penyelenggaraan pesta sakura. Musyawarah dilakukan untuk menghasilkan kesepakatan bersama yang meliputi a) Waktu penyelenggaraan; b) Tenaga dan pembiayaan; c) Sarana dan perlengkapan; d) Peserta yang akan diundang; dan e) Susunan acara pesta sakura.

Waktu penyelenggaraan pesta sakura biasanya dilakkan pada setiap awal bulan Syawal yang berlangsung selama 3 sampai 7 hari. Awal pelaksanaannya dilakukan setelah sholat 
Idul Fitri, yaitu berkisar antara pukul 09.00 - 18.00 WIB dan sudah selesai sebelum masuk waktu maghrib. Pelaksanaan pesta sakura dilakukan secara gotong royong dengan tenaga sukarela dari berbagai desa yang diundang. Biaya selama pesta berlangsung ditanggung bersama yang dilakukan melalui iuran dari setiap desa dan donatur yang disetujui dalam musyawarah.

Dalam pelaksanaannya panitia penyelenggara menyediakan sarana lapangan, tarub, dan pohon pinang beserta sejumlah hadiahnya, termasuk makan dan minum untuk tamu undangan dan peserta sakura yang terdaftar. Pekerjaan melengkapi sarana pesta dilakukan oleh tenaga sukarela dan dilaksanakan secara gotong royong.

Adapun peserta yang hadir pada pesta sakura umumnya terdiri dari kelompok ketua adat, tokoh masyarakat, sesepuh desa, beebrapa kelompok sakura helau dan sakura kamak setiap desa, dan masyarakat penonton pesta sakura. Acara pesta sakura umumnya terdiri dari pembukaan, halal bihalal (silaturahmi), doa memohon keselamatan pesta sakura, atraksi pencak silat, parade/pawai sakura kamak, pemanjatan pohon pinang (nyakak buah), dan diakhiri dengan doa rasa syukur dan memohon kesejahteraan, kemakmuran bagi masyarakat dan wilayah desa.

\section{Tahap pembukaan.}

Tahap pembukaan pesta sakura ditandai dengan tetabuhan musik yang gencar dan ramai. Musik pembuka biasanya dimainkan oleh kelompok kesenian tradisional desa setempat. Pada saat itu semua peserta sudah hadir, kelompok sakura telah menyempurnakan dandanannya. Ketika akan menuju arena, umumnya sakura belum melengkapi dan memakai busananya, baru dikenakan apabila sudah berada di dekat arena pesta di luar lapangan. Ketika bertamu, hanya satu dua orang saja yang bersakura. Setelah musik dihentikan, 
dilanjutkan dengan acara protokoler seperti sambutan dan nasehat dari ketua adat dan sesepuh desa.

Dengan dipandu pembawa acara, peserta pesta saling bersalam-salaman saling maaf-memaafkan. Pada tahapan ini sesepuh desa menjadi sasaran utama untuk disalami tamu undangan dan peserta pesta. Setelah selesai, doa pembukaan acara pesta sakura dilafalka oleh salah satu ketua adat memohon keselamatan pesta sakura, kemudian ditapilkan acara tari-tarian dan pencak silat secara resmi. Pementasan ini ditampilkan di depan tamu undangan dan penari berkostum sakura kamak. Atraksi pencak silat oleh sakura kamak merupakan acara hiburan tersendiri yang menampilkan adegan pertarungan berpasangan dan berkelompok. Setiap desa yang diundang tampil memperagakan kemahiran kreasi menari dan memainkan alat perang seperti keris, pedang, dan tongkat. Setelah acara atraksi selesai acara behenti sejenak untuk istirahat. Para peserta dipersilahkan menyantap hidangan yang disediakan panitia. Kelompok sakura juga menyantap makanan yang diperolehnya ketika bertamudi beberapa rumah penduduk.

\section{Tahap inti pesta sakura.}

Inti acara pesta sakura adalah oarade atau awai sakura dan nyakak buah. Salah satu ketua adat memimpin acara parade setelah berpamitan pada tamu undangan. Rute yang dilalui adalah jalan-jalan desa disekitar arena pesta. Setelah rute diselesaikan peserta parade beristirahat sejenak dan panitia mempersiapkan segala sesuatunya untuk acara panjat pinang. Panitia mengecek ulang daftar kelomok sakura kamak dan menentukan urut-urutan pemanjatan. Sepuluh orang sakura kamak kelompok pertama maju ke depan pohon pinang. Setelah do'a bersama, sakura kamak mengatur, menyusun strategi dan formasi pemanjatan. Sorak sorai penonton mewarnai kegagalan dan jatuh bangunnya kelompok pemanjat yang diramaikan dengan tabuhan musik pendukung 
kelompoknya. Penentuan peserta pertama pemanjatan dilakukan dengan undian, karena umumnya peserta pertama selalu gagal memperoleh hadiah. Pohon pinang yang licin dan belum tersentuh menyulitkan kelompok ini sampai ke puncak. Kelompok kedua, ketiga, keempat dans eterusnya tidak sesulit kelompok sebelumnya, karena pohon pinang sudah berkurang tingkat kelicinannya disapu oleh kelompok pemanjat pertama. Waktu pemanjatan dibatasi antara 30 sampai 60 menit dan tidak bisa dilakukan pemanjatan ulang oleh kelompok yang sama. Hadiah yang tergantung biasanya berhasil dihabiskan selama nyakak buah ini berlangsung pada hari itu juga.

\section{Tahap penutupan.}

Tahapan ini pada umumnya diisi acara doa bersama peserta pesta sakura dan diakhiri dengan musik penutup. Peserta pesta sakura dan penonton meninggalkan arena pesta. Dalam perjalanan pulang masih tersisa adegan gaya gerak pesta sakura yang berhasil merebut hadiah. Ungkapan kegembiraan diwujudkan dengan kembali beraksinya para sakura memainkan adegan sesuai dengan karakter yang diperankan.

Esok harinya masih nampak beberapa masyarakat terutama pemudanya tetap bersakura. Mereka melakukan atraksi ngamen dan terkadang bertamu ke rumah penduduk. Setelah satu minggu acara pesta sakura berlangsung meriah, penduduk kembali pada aktifitasnya masing-masing.

\section{E. Makna Simbolik Dalam Sakura}

Pesta Sakura sudah dilakukan secara turun-temurun oleh masyarakat Lampung Barat. Sebagai hasil dari kreasi imajinasi manusia, pesta Sakura dianggap memiliki makna simbolis yang mendalam. Simbol merupakan suatu unsur penting dalam kebudayaan. Bahkan sejumlah antropolog seperti Ernest Cassirer memandang bahwa simbol merupakan 
unsur dasar dari semua kebudayaan. ${ }^{32}$ Dalam pikiranmanusia, tidak hanya ada tumpukan pengetahuan atau kejadian-kejadian akibat berpikir, tetapi mempunyai kaitan dengan munculnya berbagai simbol-simbol. Manusia telah menemukan simbolsimbol dari luar dirinya. ${ }^{33}$ Penginterpretasian terhadap suatu simbol bersifat arbriter (semena-mena), dan interpretasi ini harus dilakukan tanpa melepaskan objek dari konteksnya.

Makna simbolis pesta Sakura yang dilaksanakan oleh masyarakat Lampung Barat dapat dilihat dari properti yang digunakan serta gerak tari yang diperankan di dalamnya.

\section{Makna properti pesta Sakura}

Ada dua properti yang dipakai dalam Sakura, yaitu topeng dan pakaian/atribut. Topeng merupakan properti utama dalam Sakura. Pada awalnya Sakura merupakan suatu rekayasa yang digunakan untuk pemujaan oleh sekelompok Buay Tumi pada masa prasejarah yang memiliki kepercayaan animisme. ${ }^{34}$ Pada masa ini Sakura merupakan pertunjukan yang digunakan untuk upacara pemujaan kepada penguasa alam, roh-roh nenek moyang, yang cenderungberwajah jelek dan bertatabusana dari daun-daunan atau seadanya. Sakura dahulu ditampilkan oleh masyarakat Buai Tumi di tempattempat yang dianggap keramat, seperti tempat pemujaan. Tujuan ditampilkannya sakura ini adalah untuk menghadirkan roh leluhur dan penguasa alam semesta, untuk mendapatkan perlindungan dan bantuan, serta terhindar dari kesulitan yang melanda masyarakat desa. Artinya sakura dibuat oleh masyarakat dalam berbagai kegiatan seperti habis panen padi dan pemujaan untuk keselamatan desa. Hal ini diperkuat

${ }^{32}$ Dalam F.W. Dillinstone, Daya Kekuatan Simbol: The Powers of Symbol, terj. Widyamartaya, (Yogyakarta: Kanisius, 2002), h. 10.

${ }^{33}$ Asmoro Achmadi, Filsafat dan Kebudayaan Jawa: Upaya Membangun Keselarasan Islam dan Budaya Jawa, (Surajarta: CV. Cendrawasih, 2004), h. 10.

${ }^{34}$ R. Brandon, Jejak-jejak Seni Pertunjukan di Asia Tenggara, terj. R.M. Soedarsono, (Bandung: P4ST UPI, 2003), h. 10. 
dengan bentuk artefak topeng yang menandakan adanya hubungan erat dengan pemujaan terhadap penguasa alam, leluhur, maupun terhadap roh-roh gaib. ${ }^{35}$

Dengan kata lain topeng digunakan masyarakat adat Lampung di Lampung Barat sebagai alat penggambaran dewadewa ataupun kehidupan roh-roh halus yang mempunyai sifat baik dan buruk. Penggambaran itu dimaksudkan agar memudahkan manusia berkomunikasi dengan roh-roh tersebut. Karena manusia ingin mendapatkan keselamatan, kekuatan, perlindungan dari roh-roh yang digambarkan dalam topeng tersebut.

Hal itu sejalan dengan kepercayaan masyarakat pada zaman dahulu yang menganggap roh-roh dari orang yang sudah meninggal dapat menjelma lagi di dunia ini. Apalagi orang yang mempunyai pengaruh dalam lingkungan kehidupannya, misalnya kepala suku. Setelah meninggal masyarakat masih ingin mendapatkan perlindkungab atau keselamatan dari roh kepala suku tersebut. Untuk itu mereka menghadirkan sang kepala suku yang sudah meninggal tersebut dalam wujud topeng agar lebih mudah berkomunikasi dengan rohnya. Pembuatan topeng tersebut dimaksudkan agar roh sang kepala suku tadi dapat menghuni atau menitis pada topeng tersebut, untuk selanjutnya disembah dan dihormati. Jadi mereka bukan menyembah topeng semata-mata, tetapi menyembah roh yang menghuni topeng tersebut. Dengan demikian topeng pada waktu itu dapat diartikan sebagai tanda atau lambang perwujudan roh halus. Adapun roh-roh itu mempunyai sifat bermacam-macam, misalnya ada yang jahat, baik, sakti dan sebagainya. Maka dapat diartikan pula bahwa topeng adalah sebagai lambang perwujudan tentang hal yang gaib, mistik, magis dan sebagainya.

${ }^{35}$ Mustika, Perkembangan Bentuk ..., h. 8-9. 
Dalam hal ini memang masyarakat yang masih primitif dalam mengekspresikan daya hayal mereka sering menyimpang dari wujud fisik manusia yang sebenarnya. Apalagi hal-hal yang ada hubungannya dengan objek pemujaan. Benda-benda pemujaan tersebut dapat berwujud arca-arca, topeng atau lainnya yang dianggap suci.

Dalam konteks kehidupan masyarakat adat Lampung di Lampung Barat saat ini, pemaknaan sakura sebagai simbol dewa-dewa ataupun roh leluhur tersebut sudah jarang ditemui. Sebagian besar masyarakat Lampung Barat memaknai topeng sakura sebagai simbol karakter manusia. Saat ini topeng yang dipentaskan dalam pesta sakura nampak berhubungan erat dengan karakter-karakter, suatu sifat yang melambangkan sifat-sifat atau jiwa manusia yang berbeda antara satu dengan lainnya. Perbedaan karakter antara satu orang dengan lainnya dapat dilihat pada perbedaan wajah atau muka. Karena dari wajah dapat dilihat sifat-sifat manusia. karakter wajah dapat ebrubah sesuai dengan perubahan jiwanya.

Perubahan karakter akan mengakibatkan perubahan bentuk muka. Jadi memang dari bentuk mukalah sifat-sifat manusia ataupun binatang mudah untuk digambarkan. Hanya saja kalau pada binatang karakter itu tergantung dari jenis binatangnya, misalnya ada jenis binatang buas, jinak, dan lain sebagainya.

Di samping bagian muka yang dapat dipergunakan untuk penggambaran jiwa manusia, terdapat bagian-bagian lain, seperti tangan, kaki, bahkan seluruh tubuh dapat juga sebagai lambang perwatakan. Tetapi bagian-bagian tubuh yang lain itu tidak dapat menggambarkan perwatakan sebaik bagian wajah. Hal ini karena ada anggapan bahwa muka - khususnya mata, mempunyai sifat magis dan sakti. Mata yang bulat, terbuka lebar, melotot, menyempit dan lainnya menunjukkan sifat jiwa yang berbeda, apalagi bila dibantu dengan penyesuaian bentuk-bentuk gigi, hidung, pipi dan sebagainya. 
Sebagai simbol perwatakan manusia, terdapat beberapa bentuk topeng atau sakura yang pernah digunakan, yaitu sakura anak, sakura tuha, sakura ksatria, sakura cacat, sakura raksasa, dan sakura binatang. Sebagaimana dinyatakan oleh salah seorang penari sakura, bahwa: "di antara topeng yang pernah ada dan digunakan dalam pesta sakura adalah karakter anak, orang tua, orang hamil, binatang, dan lainnya... ${ }^{36}$

Sakura anak berukuran kecil dengan tinggi $19.2 \mathrm{~cm}$ dan lebar $14.5 \mathrm{~cm}$. Mata sakura ini terbuka lebar, hidung sedang datar,mulut tertutup, ekspresi wajah tampak sedang merajuk seperti ingin menangis. Raut muka polos berwarna hitam. Sakura ini merupakan simbol karakter anak kecil yang manja dan membutuhkan kasih sayang dari orang tuanya.

Sakura tuha ekspresinya mencerminkan wajah orang tua. Goresan rambutnya jarang, disisir rapi ke belakang. Hidung sedang persegi. Mata liyepan tampak sayu mengantuk. Bibir terbuka memperlihatkan deretan gigi atas dan gigi bawah yang jarang dan dua buah gigi atas palsu (timah). Bibir bawah tebal, kerut wajah tanda sudah berumur lanjut tampak pada goresan garis pada kedua pipi. Wajahnya oval dan berwarna hitam.

Sakura ksatria, wajahnya lonjong dengan dagu lancip. bulat membelalak. Pada kedua pipi terlihat pahatan lengkung yang menggambarkan sakura memakai helm prajurit. Pahatan helm menutupi dahi, sebagian hidung dan kedua pipi bagian atas. Sakura ini berwarna hitam.

Sakura cacat. Bentuk wajahnya persegi, pupil mata bulat besar setengah menonjol ke luar. Hidung pesek, mulut terbuka dengan bibir atas sumbing. Pipi kanan lebih menonjol dari pipi kiri yang agak datar. Sepintas proposisi wajah tidak seimbang, begitu juga dengan ciri fisik tonjolan mata, pipi, dan bibir.

Sakura raksasa. Ukuran wajahnya sangat besar dengan tinggi $37.7 \mathrm{~cm}$ dan lebar $27.3 \mathrm{~cm}$. mata bulat berlubang

${ }^{36}$ Irhan, pelaku /penari Sakura, wawancara tanggal 7 September 2013. 
melotot. Hidung belalai berbentuk bulat besar bengkok ke kanan. Bibir tebal terbuka lebar menampakkan dua buah gigi palsu (timah) mulutnya dalam posisi naik ke kanan. Ekspresi wajah menakutkan dan berwarna hitam.

Sakura binatang. Sakura ini disebut juga sakura beruk. Ciri-ciri fisiknya dapat dikenali dengan wajah khusus yang mirip dengan seekor monyet. Dahi menonjol berkerut. Hidung pesek berukuran kecil lancip. Mulut tertutup lancipmenonjol agak lebar. Kedua pipi agak bulat berkerut. ${ }^{37}$

Dilihat dari pakaian yang dikenakan, terdapat dua jenis pakaian yang digunakan dalam sakura, yaitu pakaian yang bersih dan rapih dan pakaian yang kotor. Sakura yang menggunakan pakaian bersih dan rapih disebut sebagai sakura helau/kecah. Sedangakan sakura yang mengenakan pakaian kotor dan lusuh disebut sebagai sakura kamak. Dalam pandangan Fachruddin, para pemain sakura dahulu diyakini sebagai utusan penguasa yang sedang memata-matai, semacam telik sandi pada masa kerajaan, atau intel di zaman modern ini. Para pesakura ini dahulu setelah basa-basi mereka menanyakan kabar, keluarga, pekerjaan dan situasi kampung lainnya. Mereka sering menyampaikan petuah-petuah sebagaimana yang disampaikan oleh para pemimpin dan tokoh agama. Itulah sebabnya masyarakat sejak dulu selalu memberikan respon postitif atas kehadiran dan petunjuk pesakura ini. Karena mereka yakin pesakura ini adalah utusan resmi para penguasa. ${ }^{38}$

Para pesakura ini dahulu diyakini sebagai orang-orang sakti yang mampu merombak wajah dan fisik mereka sehingga tak dikenali lagi oleh masyarakat. Motif pesakura, ada seperti orang tua jompo, ada seperti manusia terkena kutukan sehingga

\footnotetext{
${ }^{37}$ Derajat, dkk., Topeng Lampung..., h. 68-69.

${ }^{38}$ Fachruddin Dani, Hitam Putih Makna Topeng Sakura, dalam http:// fachruddin54.blogspot.com. Diunduh pada Rabu, 27 Maret 2013.
} 
wajah dan fisiknua menyerupai binatang, dan lainnya. Apapun motifnya masyarakat tetap menghormati mereka.

Sakuca helau / kecah tampil secara simpati dan ucapanucapannya berbau ajakan dan himbauan untuk mematuhi peraturan. Sedangkan sakura kamak tampil secara kasar, ucapannya dahulu berbau ancaman atas pelanggaran aturan. Konon dahulu tidak jarang sajura kamak meringkus para penjahat yang dikenal masyarakat tak tersentuh aturan. Sosok sakura kamak ini benar-benar menjadi momok yang menakutkan bagi mereka yang sering melakukan tindak ejahatan yang selama ini tidak ada pihak-pihak yang berani menindaknya.

Jika dikaitkan dengan karakter manusia, wujud sakura kecah/helau dan sakura kamak ini melambangkan adanya unsur kebaikan dan keburukan dalam lakok kehidupan manusia sehari-hari. Oleh karena itu, kehadiran sakura kecah/helau dan sakura kamak ini merupakan peringatan bagi manusia untuk senantiasa melakukan kebaikan dan meninggalkan keburukan dan kejahatan. Dalam konteks perayaan hari raya idul fitri, keberadaan sakura kecah dan kamak inii melambangkan ajakan kepada masyarakat untuk saling memaafkan kesalahankesalahan yang sudah dilakukan selama satu tahun dan menggantinya dengan kebaikan-kebaikan.

Meskipun pada awalnya sakura mengandung makna perwujudan dewa-dewa, akan tetapi dalam perkembangannya mengalami pergeseran pada makna kedermawanan dan kemiskinan. Sebagaimana disampaikan oleh Riyan, bahwa: "sakura kecah melambangkan kaum dermawan, dan sakura kamak melambangkan kaum fakir miskin. Dan pada saat hari raya kedua kelompok masyarakat ini bersatu padu tanpa ada pembedaan status kaya dan miskin". ${ }^{39}$

${ }^{39}$ Riyan Ariska, Wawancara, tanggal 7 September 2013. 
Makna ini menunjukkan bahwa antara kaum dermawan dan kaum miskin (petani) harus bekerjasama, bergotong royong dalam membangun daerahnya.leh karena itu, Idul Fitri merupakan moment yang tepat untuk melebur perbedaan status sosial yang ada di masyarakat.

Pada sakura kecah, kostum yang dikenakan lebih rapi dan lebih berfariasi. Namun demikian biasanya busana sakura kecah terdiri dari baju dan celana pendek, kain panjang yang diikatkan dipinggang, ikat kepala, dan topeng. Pilihan warna kostum tersebut disesuakan dengan selera dan pemaknaan masing-masing daerah. Sebagai contoh untuk pemain sakura kecah dari daerah Kembahang mengenakan kostum serba merah bergaris kuning. Hal ini melambangkan keberanian dan kemakmuran yang diharapkan masyarakat setempat. Sementara daerah lain ada yang mengenakan kostum berwarna hijau yang melambangkan kesuburan. ${ }^{40}$

Sedangkan kostum sakura kamak biasanya dilengkapi dengan sampah, daun-daunan kering, ranting berdaun, rumput-rumputan, dan topi dari ijuk yang mencerminkan makna hutan rimba yang ada di sekitar masyarakat. Sedangkan pakaian kaus dan celana hitam menggambarkan pakaian seorang petani yang sudah lusuh, jelek, compang-camping dan kotor. Dengan demikian makna dari pakaian sakura kamak ini melambangkan ketergantungan masyarakat setempat terhadap alam atau hutan sebagai tempat mencari nafkah. Baik dengan mengolah dan menanaminya dengan berbagai tumbuhan, juga tempat masyarakat setempat melaksanakan perburuan terhadap binatang untuk dikonsumsi.

Pemeran sakura kamak hanya boleh dimainkan oleh seseorang yang sudah tidak bujang lagi atau yang sudah berkeluarga, ditunjang dengan fisik yang gagah dan kuat dan mampu melakukan gerakan lincah dan gesit. Hal ini bukan

${ }^{40}$ Irhan, Wawancara, tanggal 7 September 2013. 
hanya ditujukan untuk prosesi cakak buah (panjat pinang), tetapi juga melambangkan bahwa seorang yang sudah berumah tangga memikul tanggungjawab besar terhadap kehidupan keluarganya. ${ }^{41}$ Oleh karena itu laki-laki yang sudah berumahtangga harus mau melakukan apapun dan bekerja keras demi menafkahi keluarganya. Dalam hal ini kebiasaan masyarakat Lampung Barat adalah bertani dan berburu yang sangat menggantungkan kehidupannya terhadap alam.

\section{Gerak tari pesta sakura}

Jika dilihat dari gerakan tari sakura, nampak bahwa tidak ada aturan atau pakem tertentu yang digunakan dalam pesta Sakura. Artinya para pesakura bebas melakukan gerak apapun disesuaikan dengan topeng yang dikenakannya. Hal ini berbeda dengan kebanyakan tari tradisional di nusantara. Hampir seluruhnya mengenakan pakem gerakan tertentu, seperti tari Gambyong (Jawa Tengah), Jaipong (Jawa Barat), Kecak (Bali), Saman (Aceh), dan lainnya.

Tarian apapun dapat ditampilkan menurut kehendak nurani sakura dengan membuat gerakan improvisasi tersendiri mengikuti irama musik. Gerakan-gerakan sakura semacam ini dilakukan untuk menampilkan emosi dan kreativitas penari mengikuti karakter topeng yang dipakainya. Beberapa karakter manusia yang pernah dimainkan pada sakura antara lain:

1. Karakter bayi. Karakter ini dimainkan dengan sering tidur-tiduran, menangis dan mengisap jempol dan dot.

2. Karakter anak-anak. gaya gerakannya meliputi berlari lincah kesana kemari, melompat, jongkok, menangis, menutup wajah dengan kedua tangan. Tingkah lakunya mencerminkan seorang anak yang sedang bermain dan berselisih dengan temannya.

3. Karakter gadis. Gaya gerak yang ditampilkan berupa berjalan gemulai, goyang pinggul, kedua tangan

${ }^{41}$ Ibid. 
mengibas rambut, kedua belah tangan menepuk dan mengelus wajah seolah sedang bersolek.

4. Karakter wanita hamil. Sakura menampilkan gerakan jalan kaki mengangkang, berjalan dengan perut ke depan sambil mengelus-elus perutnya yang hamil dibungkus buntelan kapuk/bantal.

5. Karakter orang tua/ kakek. Gerakannya dilakukan dengan berjalan terbungkuk-bungkuk, batuk-batuk, badan lemah lunglai, duduk termenung dengan pandangan kosong sambil merokok. Biasanya dilengkapi dengan sepotong tongkat atau kayu.

6. Karakter orang bijak/sakti. Gaya gerakanya meliputi berjalan tenang menatap tajam ke depan, menganggungangguk, mengelus jenggot, memberi petuah, merapal mantera, unjuk kesaktian kebal senjata tajam.

7. Karakter orang jahat/raksasa. Gerakannya dengan berjalan gagah, galak, tangan mengepal, tertawa terbahak-bahak menyeramkan, seolah-olah bergaya beringas.

8. karakter pengantin. Diperankan sepasang sakura yang mencerminkan laki-laki dan perempuan. Keduanya berjalan perlahan bergandengan tangan, terkadang berperilaku mesra dan genit kepada pasangannya.

9. Karakter orang sakit gigi. Gaya gerakannya meliputi duduk, berdiri, bererilaku tidak tenang sambil memegang salah satu pipi atau gigi, dan mencopot gigi. Gaya gerak ini menunjang bentuk sakura dengan pipi bengkak.

Banyaknya macam gerak topeng yang dimainkan itu meniru pada aneka ragam kehidupan kita, ada bayi, ada anakanak, dewasa, menikah, lalu jadi orang tua, dan akhirnya mati. Tidak mesti para pemain sakura itu memahami apa makna 
gerakan yang ditampilkannya. Namun jika disatukan itu menunjukkan siklus kehidupan manusia di dunia ini. ${ }^{42}$

Berangkat dari uraian di atas, gerak tari yang dimainkan pada pesta Sakura sebenarnya menggambarkan perjalanan hidup manusia. mulai dari kelahiran atau anak, berumah tangga, hingga kematian. Pemahaman semacam ini serupa dengan konsep sangkan paraning dumadi dalam kebudayaan Jawa. Dalam hal ini gerakan topeng Sakura yang meniru gerakan perkembangan hidup manusia mengandung makna ajaran tentang asal-usul kejadian manusia serta tujuan akhir kehidupannya.

Tidak adanya pakem dalam gerakan Sakura mengandung makna bahwa manusia bebas diberi kebebasan untuk memilih dan menentukan peran kehidupan yang akan dimainkannya. Manusia bebas memilih dan menentukan tingkah laku dan perbuatannya. Artinya baik dan buruk perbuatan manusia ditentukan oleh dirinya sendiri. Jika ditarik dalam konsep teologi Islam, paham semacam ini sejalan dengan konsep aliran Qadariyah yang meyakini bahwa perbuatan manusia ditentukan oleh dirinya sendiri, bukan ditentukan Tuhan layaknya wayang yang dimainkan oleh sang dalang.

Selain gerakan tari yang bebas, dalam pesta sakura juga terdapat atraksi gerak pencak silat. Hal itu melambangkan pertempuran atau perjuangan yang harus dihadapi oleh manusia dalam kehidupannya. Pertempuran yang paling utama berada dalam dirinya sendiri, yaitu antara kekuatan jahat dan kekuatan baik.

\section{Musik pengiring}

Proses pelaksanaan pesta sakura diiringi oleh musik tradisional. Beberapa peralatan yang digunakan antara lain talo balak, kendang, rebana, tepukan tangan dan teriakan. Sebagaimana dalam gerak, pada musik pengiring ini juga

${ }^{42}$ Matnu, Wawancara, tgl. 8 September 2013. 
tidak ada pakem tertentu yang harus diikuti, tetapi lebih pada improvisasi pemain musik dalam menyesuaikan dan memberi rangsangan pada pemain sakura dalam melakukan beragam gerak tari dan peniruan tingkah laku manusia. Hal ini melambangkan kebebasan irama kehidupan yang akan dimainkan oleh manusia. tergantung kepada manusianya sendiri yang bisa menentukan bagaimana baik-buruknya kehidupannya di dunia.

\section{F. Penutup}

Sebagai sebuah seni tradisional, pesta Sakura dilaksanakan oleh masyarakat adat Lampung di wilayah Lampung Barat setiap awal bulan Syawal. Tujuannya adalah untuk memeriahkan perayaan Idul Fitri. Sakura dilaksanakan dibeberapa tempat (desa) yang berbeda secara bergantian. Sakura dilaksanakan dengan mengenakan topeng yang meniru tokoh dan perwatakan tertentu.

Sebagai hasil dari kreasi imajinasi manusia, Sakura memiliki makna simbolis yang mendalam. Hal itu nampak dari properti yang digunakan, gerak tari, dan iringan musiknya. Topeng sebagai properti utama pesta Sakura menggambarkan perwujudan karakter manusia. Adapun pakaian yang dikenakan sakura melambangkan adanya dua karakter perbuatan manusiam, yaitu baik dan buruk. Selain itu Sakura Helau dan Kamak juga melambangkan adanya dua lapisan masyarakat, yaitu kelompok dermawan dan kelompok miskin. Kehadiran sakura helau dan kamak mengajarkan kepada masyarakat agar kedua kelompok tersebut untuk menghilangkan perbedaan status sosial dan bersatu padu bekerjasama da;am memajukan daerahnya. [.] 


\section{DAFTAR PUSTAKA}

Achmadi, Asmoro, Filsafat dan Kebudayaan Jawa: Upaya Membangun Keselarasan Islam dan Budaya Jawa, Surajarta: CV. Cendrawasih, 2004.

Bakhtiar, Amsal, Filsafat Agama, Wisata Pemikiran dan Kepercayaan Manusia, Jakarta: PT. Raja Grafindo Persada, 2007.

Bandem, I Made dan Rembang, I Nyoman, Perkembangan Topeng Bali Sebagai Seni Pertunjukan, Bali: Proyek Penggalian Pembinaan Pengembangan Seni Klasik/Tradisional dan Kesenian Baru Pemerintah Daerah Tingkat I Bali, 1976.

Brandon, R., Jejak-Jejak Seni Pertunjukan di Asia Tenggara, Terj. RM. Soedarsono, Bandung: P4ST UPI, 2003.

Canggu, Endang Guntoro, Tradisi dan Masa Depan Kekuatan Sebuah Kebudayaan: Memaknai Pesta Budaya Sekura Cakak Buah di Lampung Barat, dalam http//www.endangguntoro canggu.blogspot.com/2009/02/tadisi-dan-masa-depankekuatan-sebuah.html.

Daeng, Hans J., Manusia, Kebudayaan dan Lingkungan, Tinjauan Antropologis, Yogyakarta: Pustaka Pelajar, 2000.

Derajat, Endjat Djaenu, dkk, “Topeng Lampung: Tinjauan Awal Drama Tari Tupping dan Pesta Sakura", Bandar Lampung : Departemen Pendidikan dan Kebudayaan Kantor Wilayah Propinsi Lampung, 1993.

Dillinstone, F.W., Daya Kekuatan Simbol: The Powers of Symbol, terj.

Widyamartaya, Yogyakarta: Kanisius, 2002.

Fachrudin, dalam http:|/fachruddin54.blogspot.com/2009/09/ hitam-putih-makna-topeng-sakura.html,

Geertz, Clifford, Tafsir Kebudayaan, Yogyakarta: Kanisius, 1992.

Herusatoto, Budiono, Simbolisme Dalam Budaya Jawa, Yogyakarta: Hanindita Graha Widia, 2000. 
Hot, Claire, Melacak Jejak Perkembangan Seni di Indonesia, terj. RM. Soedarsono, Bandung: Masyarakat Seni Pertunjukan Indonesia, 2000.

http://blog.ugm.ac.id/2010/10/30/pesta-rakyat-topeng-sekura-didesa-pangkul/.

Jandra, Mifedwil, dkk., Perangkat/Alat-alat dan Pakaian Serta

Makna Simbolis Upacara Keagamaan di Lingkungan Keraton Yogyakarta, Yogyakarta, Proyek Inventarisasi dan Pembinaan Nilai-nilai Budaya DIY, 1989-1990.

Kawindrosusanto, Kuswadji dan Rachmadi Ps, Topeng-topeng Klasik Indonesia, Yogyakarta: Panitia Pameran Topeng Klasik Indonesia Yogyakarta, 1970.

Koentjaraningrat, Pengantar Ilmu Antropologi, Jakarta: Aksara Baru, 1980.

Koentjaraningrat, Sejarah Teori Antropologi II, Jakarta: UII, 1990. Mustika, I Wayan, Perkembangan Bentuk Pertunjkan Sakura Dala Konteks Kehidupan Masyarakat Lampung Barat Tahun 19862009, Ringkasan Disertasi dalam Rangka Ujian Terbuka, UGM Tahn 2011.

Peursen, C.A. Van, Strategi Kebudayaan, terj. Dick Hartono, Yogyakarta: Kanisius, 1976.

Sachari, Agus, Estetika: Makna, Simbol dan Daya, Bandung, ITB, 2002.

Samovar, Larry A., dkk, Komunikasi Lintas Budaya, Jakarta: Salemba, 2010.

Sobur, Alex, Psikologi Umum, Bandung: Pustaka Setia, 2003.

Spradley, James P., Metode Etnografi, Yogyakarta: Tiara Wacana, 1997.

Subagya, Rahmat, Agama Asli Indonesia, Jakarta: Sinar Harapan, 1981. 
Supadmi, Murtiadji, R. Sri dan Suwardanidjaya, R., Tata Rias Pengantin Gaya Yogyakarta, Jakarta: Gramedia Pustaka Utama, 1993. 